\title{
The effectof using reciprocal teachingtowards students' reading ability of recount text inthe eighth grade of SMPN 1 Sine
}

\author{
S. Sukini ${ }^{1}$, Nuri Ati Ningsih ${ }^{1}$, Dwi Rosita Sari ${ }^{1}$ \\ ${ }^{1}$ Department of English Teaching, Universitas PGRI Madiun, Indonesia
}

\begin{tabular}{l}
\hline Article Info \\
\hline Article history: \\
Received January 8, 2018 \\
Revised March 21, 2018 \\
Accepted Mei 30, 2018 \\
\hline
\end{tabular}

Keywords:

Reciprocal Teaching

Teaching Reading

Recount Text

\begin{abstract}
The purpose of this research is to know the effects of Reciprocal Teaching toward students's reading ability of recount text in the eighth grade of SMPN 1 Sine in the Schooling year of 2016/2017. Reciprocal Teaching has four strategies, such as; Predicting, Questioning, Clarifying and Summarizing. The method that is used by the researcher is Experimental Design. The researcher used two classes, the first class as control class and the other one is expeimental class. Each class consists of 20 students. They had different treatment. The control class is not treat by the Reciprocal Teaching but the experiment class treated Reciprocal Teaching. The researcher got the data by using pretest and postest for each class. The test is 50 items of multiple choices. The researcher used SPSS v23 to count the result of the data. The data analysis showed the significancy of the data. The mean score for experimental group has 49,20 . Then, the mean score for control group has 43,25 . Based on the two means, it can be considered that both of the groups are significantly different. The results of the sig. of the Lavene's test for equality of variances show that it exceeds the level of tolerance p. value .05. The result of sig. is .095. It means that there is no significant different from the two groups and Ho can be rejected. The mean score for group which is treated by using Reciprocal Teaching has 79,55 . Then, the mean score for the group which is not treated by using Reciprocal Teaching has 73, 55. The results of post-test both of the groups show significantly different. The result of independent sample t-test shows the significantly different can be seen from the sig. 004 in t-test for equality of means. This result is lower than the $\mathrm{p}$ value .05 of significance tolerance. It can be concluded that Reciprocal Teaching Technique is effective toward students' reading ability of recount text in the eighthgrade of SMPN 1 Sine.
\end{abstract}

Copyright (c) 2018 Department of English Teaching. All rights reserved.

\section{Corresponding Author:}

Sukini,

Department of English Teaching,

Universitas PGRI Madiun,

Jalan Setiabudi No.85 Madiun, Eas Java, Indonesia.

Email: sukinisuki4@gmail.com

\section{INTRODUCTION}

Reading is the important aspect of education. By reading, students will understand the knowledge. It is not only about the knowledge but also increase the understanding of politics, economics, social etc. Reading is one of the skill that should be mastered in studying English. Mastering reading will give many advantages for students. Reading feeds the craving mind, improves their quality of conversations, helps the students to tap in the mind of the creative thinkers, all leaders and successful people is caused by reading, and stimulates your creativity. So, the researcher concludes those activities are important for students in improving their reading skill. Reading is not only about the process but also the product of reading. Alderson and Bachman (2000:03) suggested that the nature of reading are separated into two, those are the process of reading and 
result of that process, named product. In the other words, reading activitiesare devided into two, the reading process and the reading product. In addition, the process of reading done trough several stages.

Meanwhile, there is no specific teaching technique that focuses on reading comprehension. When it comes to reading, the teacher only asks the students to read the text and answer the comprehension questions provided in the textbook. As the result, the students tend to have poor reading skill and habit. The matter arises because of some factors: (1) Students are difficult to understand the text by theirselves. (2) The text is not interesting. (3) The teaching technique which is used by the teacher is boring enough. (4) The text is too hard. (5) Students believe when comprehending the text, they should comprehend every single word in the text, so they keep on looking up the words in a dictionary to find out the meaning of the words, (6) both students and teacher have very limited techniques and strategies in reading.

Based on the problems, the teachers should use strategy to create students better understanding. The researcher proposes one technique that can be used to improve students' comprehension. The technique proposed is Reciprocal Teaching. Reciprocal Teaching is a process to comprehend text by using students experiences to build their speculation about the text. As stated by Cooper and Greive (2009: 46) encouraging the early development of students' reading comprehension can be done by teaching the primary students a metacognitive approach to reading. Using Reciprocal Teaching, will help teacher to dig up the students'reading ability. There are many reasons why Reciprocal can be used in teaching reading. First, Reciprocal Teaching contains main organized strategies (predicting, clarifying, questioning and summarzing) which leads teacher to teach in good steps. Each step has different strategy to help students' understanding. Second, Reciprocal Teaching provides the students chances to share and improve their ideas with their groups. In short, it can be concluded that this strategy should be applied because it will make students easier to read and comprehend text. To Support this research, the researcher finds previously research by another researcher that shows Reciprocal Teaching is effective to teach reading and to improve the students' reading comprehension.

The previously research was written by Tan Ooi Leng Choo and friends. The title is "Effects of Reciprocal Teaching Strategies on Reading Comprehension", This article discusses how 'Reciprocal Teaching Strategies' could help low-proficiency Sixth-Form students in improving their reading comprehension. A study using a quasi-experimental design was conducted among 68 low-proficiency students from four Sixth-Form, intact classes. An intervention of nine reading lessons using Reciprocal Teaching strategies was administered over a period of one month. Tools for data collection were a pretest, a posttest and five open-ended questions given after the treatment. The findings from the independent t-test and paired-sample t-tests showed a significant difference, revealing the effectiveness of the strategies, and the respondents from the Experimental Group gave positive feedback regarding the use and effects of these strategies. The article concludes with implications for pedagogy and research.

The other previously research, according to thesis by Melani from English Department Language and Art Faculty of UNIVERSITAS NEGERI PADANG by the title "The Effect of Reciprocal Teaching Technique towards Students' reading ability of second grade of students of SMAN 4 Padang" showes that based on the finding, it could be seen that reciprocal teaching could better effect on students' ability in reading. The mean score of the experimental class was 62.7 while the control class was 55. 4. However, from the posttest score which was assigned after the treatment, it can be stated that the reading scores of both 
of the classes increased. In pretest, the mean scores of experimental class was 62.5 and it was increased become 69.4. Meanwhile, the mean score of the control class was 55. 4. And it increased into 64.86 in the posttest. In facts the experimental class obtained higher score than the control class in the posttet. The mean score of the experimental class was 69.4 and the control class was 64.86. it means the difference was statistically significant.

\section{METHOD}

In this research, the researcher uses quantitative research. Quantitative research is a formal, objective, systematic process in which numerical data are used to obtain information about the world. Based on Creswell (2009: 178) Quantitative reseach is a means for testing objective theories by examining the relationship among variables. These variables can be measured and typically on instruments, so that numbered data can be analyzed using statistical procedures. The final written report has a set structure consisting of introduction. literature and theory, methods, results, and discussion. The design that suitable with the research is a quasi-experimental design. It is employed using two intact classes. A class is randomly assigned to the Experimental Group, while the other one was randomly assigned to the Control Group. The procedures of the research design were as follows:

1. Giving homogeneous test to all classes of the eighth grade in order to know the homogeneity of the population.

2. Determining the experimental group and the control group by using random sample.

3. Giving pretest to know the comprehend of the student.

4. Giving treatment to the experimental group, that was teaching reading comprehension by using Reciprocal Teaching, while the control group was taught reading by using discussion technique as usually applied by the English teacher. In this research, the students were taught reading by the researcher.

5. The teaching learning process of reading was conducted in two meetings for both groups. Every meeting lasted for 80 minutes.

6. Giving the reading posttest to both groups to measure the students'reading comprehension achievement after the treatments were given to the experimental group and control group was taught reading by using discussion technique.

7. Analyzing the results of reading posttest scores by using Independent Sample t-test with SPSS (Statistical Package for Sosial Science) to compare the result of the reading scores between the experimental group and the control group. The results were compared to see whether or not there was a significant effect of using Reciprocal Teaching on the students' reading comprehension.

8. Drawing a conclusion from the result of the data analysis to answer the research problem.

The research uses pretest and posttest. The researcher uses this technique to get the data. Those are Pretest and Post-Test. The test is 30 multiple choises for both groups. The main data of this research that was the students' scores of reading comprehension achievement test were analyzed by using independent sample tTest which is available on SPSS (Statistical Package of Social Science) 23.0. In this research, t-Test was used to know the mean difference between two different independent groups namely experimental and control 
groups. The data was analyzed quantitatively by using Independent Sample t-Test with 5\% significant level (confidence interval 95\%) and degree of freedom (df). The results of analyzing data were used to know whether or not there is a significant effect of using Reciprocal Teaching Technique on the students' reading comprehension achievement. The hypotheses were as follows:

H0: There is no significant effect of using Reciprocal Teaching Technique on students reading comprehension achievement.

H1: There is significant effect of using Reciprocal Teaching Technique on students reading comprehension achievement.

The decision to determine that the means between the two groups are the same was based on the following criteria:

If the probability (Asymp. Sig.(2-tailed)) $\geq 0.05, \mathrm{Ho}$ is accepted.

If the probability (Asymp. Sig.(2-tailed)) $\leq 0.05, \mathrm{Ha}$ is accepted.

\section{RESULT AND DISCUSSION}

This section consists of he results of the research. There are several results relate to the research questions. The results show the descriptive statistics and independent sample t-test.

Table 1 Descriptive Statistics pre-test both of group which were treated and which were not treated by using Reciprocal Teaching

\begin{tabular}{lllccc}
\hline & \multicolumn{5}{c}{ Group Statistics } \\
\hline GRETEST SCORE & EXPERIMENT & 20 & 49,20 & 6,849 & Std. Error Mean \\
\cline { 2 - 6 } & CONTROL & 20 & 43,25 & 3,582 & 1,531 \\
& & & Mean & Std. Deviation &, 801 \\
\hline
\end{tabular}

Based on the table 1 it can be seen that the mean score for both groups are very close. The mean score for experimental group has 49, 20. Then, the mean score for control group has 43, 25. According to the two means, it can be considered that both of the groups are significantly different. But, this is not enough to state that the two groups are homogenity. The following is independent sample t-test used to know the significance different both of the groups.

Table 2 Represents Independent Sample t-test (Pretest both of groups which were treated and which were not treated by Reciprocal Teaching)

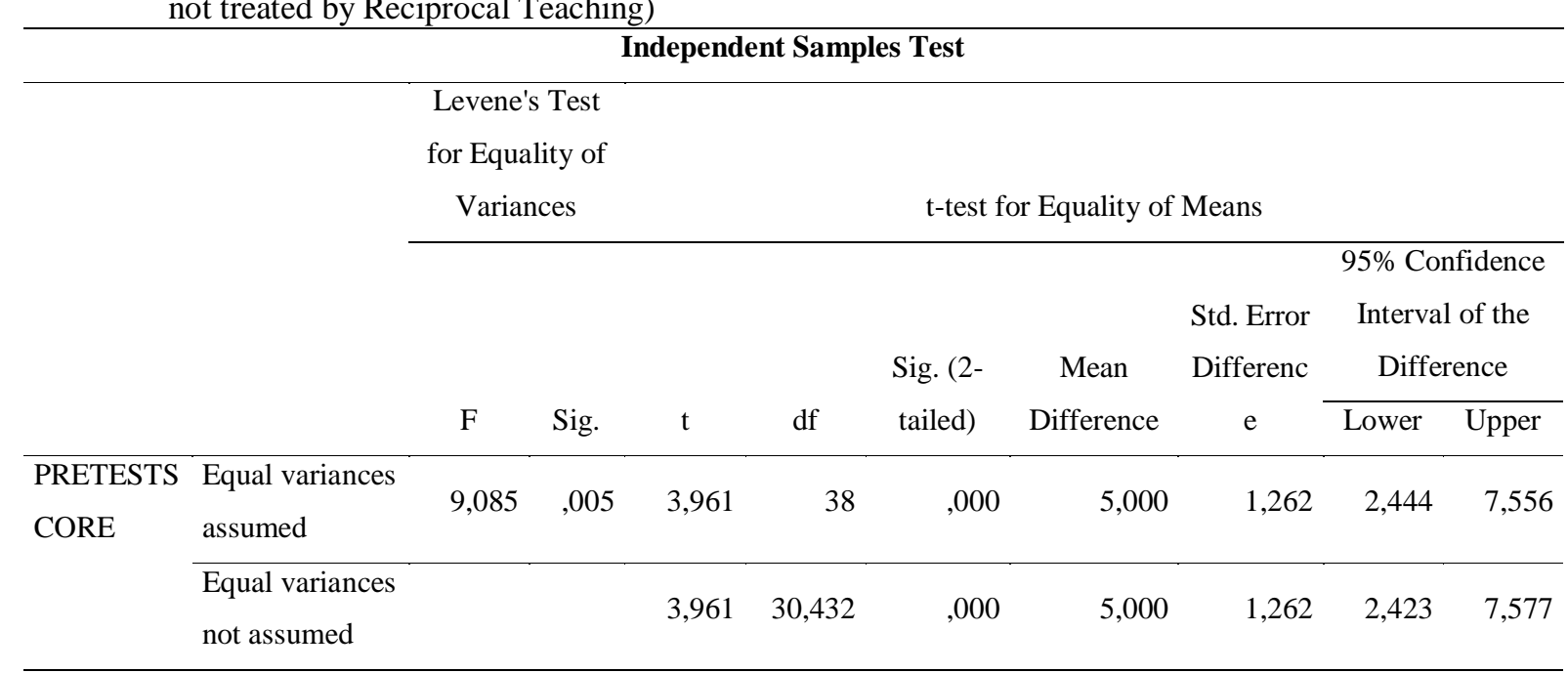


Table 2 represents the independent sample t-test to see or not two groups are homogenity. The results of the sig. of the Lavene's test for equality of variances show that it is lower than the level of tolerance p. value .05 . The result of sig. is .005 . It means that there is significant different from the two groups. It means the variances are the similar or the data are homogenity. It means that, table 4.4 shows the homogeneity of the two groups. After knowing that the two groups are homogeneity the treatments were given both of the groups. The first group was treated by using reciprocal teaching and the second group was not treated by using Reciprocal Teaching.

Table 3 Represents the descriptive statistics post-test both of the groups namely the groups which were treated and which were not treated by using Reciprocal Teaching.

\begin{tabular}{llccrrr}
\hline \multicolumn{7}{c}{ Group Statistics } \\
\hline & GROUP & $\mathrm{N}$ & Mean & \multicolumn{2}{c}{ Std. Deviation } & \multicolumn{2}{c}{ Std. Error Mean } \\
\hline POSTTESTS & EXPERIMENT & 20 & 79,55 & & 5,942 & 1,329 \\
\cline { 2 - 7 } CORE & CONTROL & 20 & 73,55 & 3,268 &, 731 \\
\hline
\end{tabular}

Based on the table above, it can be seen that the mean score for both of the groups are different. The mean score for group which is treated by using Reciprocal Teaching has 79, 55. Then, the mean score for the group which is not treated by using Reciprocal Teaching has 73, 55. Based on score, it can be considered that both of the groups are significantly different. But, this is not enough to state that the two groups are significantly different. The following is independent sample t-test used to know the significance different both of the groups.

Table 4 Represents Independent Sample t-test (Post-test both of groups which were treated and which were not treated by Using Reciprocal Teaching)

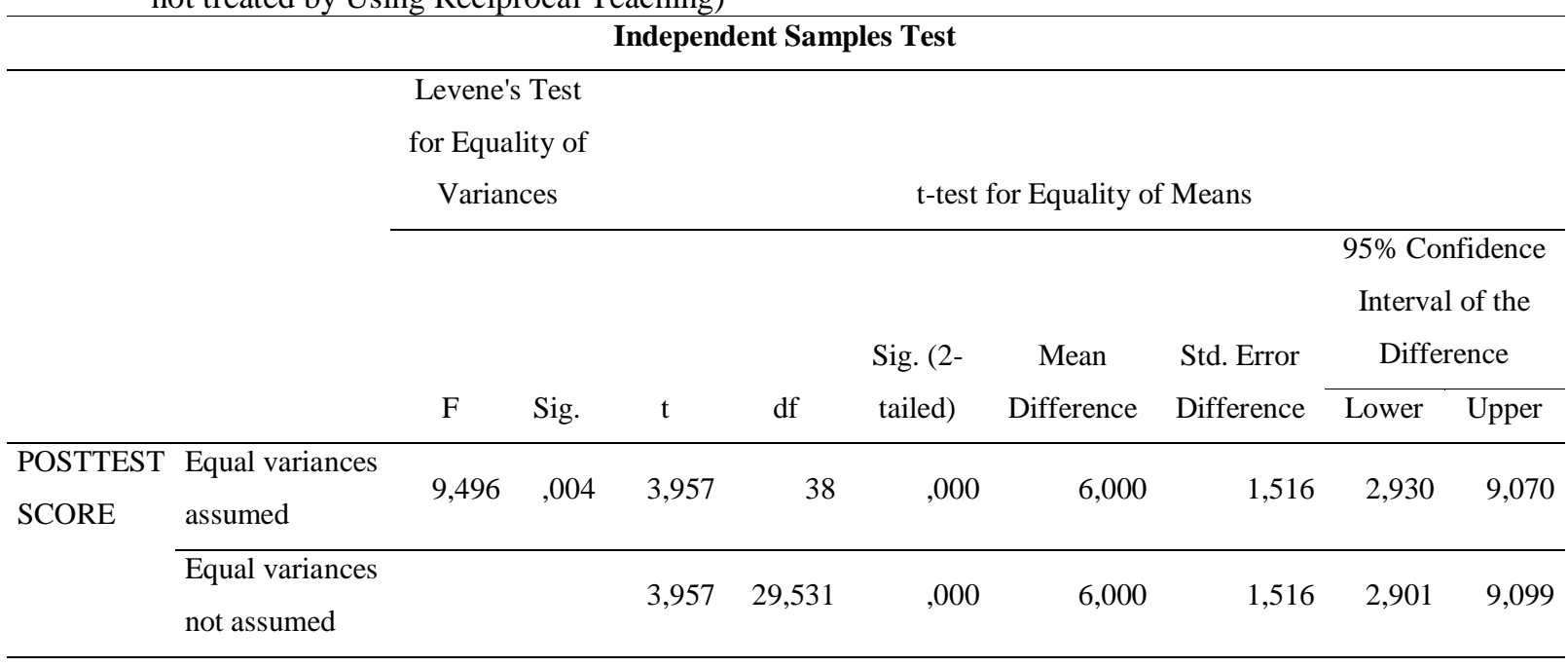

Table 4 above shows the analysis of the post-test both of the groups; the groups which was treated by using Reciprocal Teaching and the group which was not treated by using Reciprocal. The analysis was done by using independent sample t-test. The result of independent sample t-test shows the significant different can be seen from the sig. 004 in t-test for equality of means. This result is lower than the p value .05 of significance tolerance. The two groups are significantly different. The groups which was treated by using Reciprocal Teaching and the group which was not treated by using Reciprocal Teaching are significantly different. But, from this explanation the students who are treated by using Reciprocal Teaching have better 
reading than the students who are not treated by using Reciprocal Teaching. It can be concluded that there is significant different from the two groups of equality of means. This means that $\mathrm{H}_{\mathrm{O}}$ can be rejected.

In this section, the researcher discusses the results of the study about the effect Reciprocal Teching toward Students' Reading Ability. There are two main discussions about, pre-test and post-test. The results of pre test both of the groups are very close. It means that the two groups are homogeneity. The mean score for group which is treated by using Reciprocal Teaching has 49. 50. Then, the mean score for the group which is not treated by using Reciprocal Teaching has 42. 30. The mean score of the two groups are considered significantly different. Furthermore, the results of the sig. of the Lavene's test for equality of variances show that it exceeds the level of tolerance p. value .05. The result of sig. is .005 . It means that there is significantly different from the two groups and $\mathrm{H}_{\mathrm{O}}$ can be rejected.

The results of post-test both of the groups show significantly different. The result of independent sample t-test shows the significant different can be seen from the sig. 004 in t-test for equality of means. This result is lower than the $\mathrm{p}$ value .05 of significance tolerance. The two groups are significantly different. From the results, it can be seen that the students who are treated by using Reciprocal Teaching have better reading than the students who are not treated by using Reciprocal Teaching. It can be stated that there is significant different from the two groups of equality of means. It can be said that using Reciprocal as the authentic materials can help the student have better reading of recount text.

Based on the result of post test, it can be seen that the effect of Reciprocal Teaching has better reading of recount text. It is obviously similar from the previous assumption that using Reciprocal Teaching the students will have better reading of recount text. Based on the teaching learning process in experimental group, the students were so excited and interested in participating in Reciprocal Teaching Technique. They were also involved in teaching learning process by doing the four strategies. From the activities done in the classroom, the students from experimental group could understand and comprehended the content of the material better than the control group. They also showed better enthusiasm in reading activity, and they enjoyed working in groups. The results of the data analysis above were in line with what was described by Hartman (1997) stating that the advantages of Reciprocal Teaching Technique are (1) students are actively engaged in learning, (2) reading strategies are used in an integrated, coordinated way in a meaningful context, (3) students enjoy working together and being 'teachers', (4) students are able to learn with the benefit of repeated tutor modeling and learn to take responsibility for their own and each others learning.

In addition, the use of four instructional foundations (scaffolding, thinking aloud, cooperative learning and metacognition) proved that it helped both the teacher and the students in the application of predicting, questioning, clarifying and summarizing effectively. In scaffolding, the students could see the models of the four strategies, experienced as they try out Reciprocal Teaching Technique in a supported environment and worked independently which can promote group interaction with thinking aloud assisted in each steps. Moreover, Reciprocal Teaching Technique also provided effective metacognition because it helped the students to monitor their own reading in order to overcome any difficulties in their reading. In other words, the four strategies with the four instructional foundations helped students overcome difficulties when reading text as they evaluated their reading comprehension. In relation to this the theory, this research finding is in line with the statement from Foster and Rotoloni (2012), state that effective Reciprocal Teaching Technique lesson includes scaffolding, thinking aloud, using cooperative learning, and facilitating metacognition in each 
step. Reciprocal teaching is a teaching strategy that helps students to increase their ability involving them to the discussion by using four steps; predicting, clariying, questioning and summmarizing. The result of this research could prove that the use of Reciprocal Teaching strategy could give better effect on the students' reading ability. In addition, students could clearly understand about recount text. They able to understand the social function of recount text, the language features, and detailed information containing in the recount text.

\section{CONCLUSSION}

Regarding from the description of the data, the analysis of the data and the discussion, it can be seen that the result of pretest both of experimental and control class is significant different. Those are 49. 50 for experimental class and 42. 30 for control class. The result of postest both experimental and control is also significant different. Those are 79, 55 for experimental class and 73, 55 for control class. Furthermore, the results of the sig. of the Lavene's test for equality of variances show that it exceeds the level of tolerance p. value .05 . The result of sig. is .005 . It means that there is significantly different from the two groups and $\mathrm{H}_{\mathrm{O}}$ can be rejected. The results of post-test both of the groups show significantly different. The result of independent sample t-test shows the significant different can be seen from the sig. 004 in t-test for equality of means. This result is lower than the $\mathrm{p}$ value .05 of significance tolerance. The two groups are significantly different. it can be concluded that there is a significant effect of using Reciprocal Teaching toward students' reading ability of recount text in $8^{\text {th }}$ grade at SMP Negeri 1 Sine in the Schooling Year 2016/2017.

\section{REFERENCES}

Alderson, C. J. (2000). Assessing Reading. Cambridge: Cambridge University Press.

Arikunto, S. (2011). Prosedur Penelitian Suatu Pendekatan Praktik. Jakarta: Rineka Cipta.

Berardo, S.A. (2006). The Use of Authentic Materials in the Teaching of Reading. The Reading Matrix, Vol.6, No. 2, 60-67. www.readingmatrix.com/articles/berardo/article.pdf. Accessed on 27 September 2011.

Brown, D.H. (2000). Principles of Language Learning and Teaching fourth edition. San Francisco: Addison Wesley Longman, inc.

Brown, D.H. (2004). Language Assessment Principles and Classroom Practices. San Francisco: Pearson education, inc.

Choo, T.O. L, Eng T.K and Ahmad, N. (2011). Effect of Reciprocal Teaching Strategies on Reading Comprehension. The Reading Matrix, Vol.11, No 2, 141-142. www.readingmatrix.com/...2011/. Accessed on 30 March 2012.

Cooper, T. and Greive, C. (2009). The Effectiveness of the Methods of Reciprocal Teaching. ResearchOnline@Avondale, 45-47. research.avondale.edu.au/. Accessed on 29 March 2012.

Grabe, W. (2009). Reading in a Second Language Moving From Theory to Practice. New York: Cambridge University Press.

Klingner, J.K., Vaughn, S. \& Boardman, A. (2007). Teaching Reading Comprehension to Students with Learning Difficulties. New York: The Guilford Press.

Oczkus, L. D. (2005). Reciprocal Teaching Strategies at Work. New York: International Reading Association.

Palincsar, A. S. \& Brown, A. L. (1984). Reciprocal Teaching of Comprehension Fostering and Comprehension-Monitoring Activities. Cognition and Instruction, 1, 117-175. 
Siahaan S \& Shinoda K, 2008. Generic text structure Yogyakarta: Graha Ilmu.

Sugiyono, 2013. Metode Penelitian Manajemen Pendekatan: 1. Kuantitatif, 2. Kualitatif, 3. Kombinasi (Mixed Methods), 4. Penelitian Tindakan (Action Research), 5. Penelitian Evaluasi. Bandung: Alfabeta.

Widiati, U., Gunadi, H. S., Nunung, S., Slamet, S., Pratiwi, R. 2008. Contextual Teaching and Learning Bahasa Inggris: Sekolah Menengah Pertama/Madrasah Tsanawiyah Kelas VIII Edisi 4. Jakarta: Pusat Perbukuan, Departemen Pendidikan Nasional. 